\title{
UNCONSTITUTIONAL LEGISLATIVE SOLUTIONS IN THE FIELD OF EDUCATION
}

DOI: 10.47743/rdc-2017-1-0004

\section{Tudorel TOADER ${ }^{1}$}

ttoader@uaic.ro

Marieta SAFTA ${ }^{2}$

marieta.safta@ccr.ro

\section{Abstract}

The study continues the presentation of the evolution of the jurisprudence of the constitutional litigation court, from the finding of the unconstitutionality of the legal norm, to the finding of the unconstitutionality of the legal solution promoted by that norm, with punctual reference to the field of education. By pointing out both the sanctioning effect on the norm that was the subject of the exception of unconstitutionality and the preventive effect of constitutional control, in order to stop the legislator from resuming a declared unconstitutional legislative solution, unless there is a change of context socio-economic, the jurisdiction of the Constitutional Court appears as an important legal security factor.

Keywords: unconstitutional legislative solutions; constitutional control; education; the constitutionalization of the law

\section{There can be no violation of the right of parents or guardians to ensure,} according to their own religious convictions, the education of minors under their responsibility

The legislative solution declared unconstitutional was enshrined in the provisions of Article 9 para. (1) of the National Education Law, provisions according to which: "Primary, secondary, lycee and vocational education plans include religion as a school discipline. In primary education, religion is a mandatory discipline, in gymnasium it is optional, and in high school and vocational education it is optional. The pupil, with the

\footnotetext{
${ }^{1}$ Professor, PhD, Rector of “Al.I. Cuza” University of Iaşi, Judge of the Romanian Constitution Court of Romania (October 2006-July 2016), Minister of Justice.

2 Associate Professor, PhD, Faculty of Law of "Titu Maiorescu" University of Bucharest, First assistant-magistrate at the Romanian Constitutional Court of Romania, Secretary of State.
} 
consent of the parent or legal guardian instituted, chooses to study religion and confession". The objection of incoherence only referred to the second sentence of Article 9 para. (1), namely that in primary education "religion is a mandatory discipline".

The provisions challenged in terms of constitutionality have been examined in the light of several norms contained in the Basic Law, as well as in the Universal Declaration of Human Rights, in pacts and in international conventions that are directly incidental. Thus, according to Article 32 para. (7), the final sentence of the Constitution, "in state schools, religious education is organized and guaranteed by law"; according to Article 29 para. (1), the final sentence of the Constitution, "no one can be compelled to adopt an opinion or adhere to a religious belief, contrary to his convictions"; according to Article 29 para. (6) of the Constitution, "parents or guardians have the right to ensure, according to their own convictions, the education of minors under their responsibility". For the purposes of Article 18 of the Universal Declaration of Human Rights, everyone has the right to freedom of thought, conscience and religion, including the freedom to change their religion or belief, and the freedom to manifest their religion or belief, and Through teaching; Article 18 para. (1) of the International Covenant on Civil and Political Rights contains identical rules, but, in para. (2), it is added that "no one shall be subject to any constraint which may prejudice its freedom to Have or adopt a religion or conviction of his choice"; by Article 13 para. 3 of the International Covenant on Economic, Social and Cultural Rights, the States Parties to this pact committed themselves to respecting the freedom of parents and, where appropriate, legal guardians to "provide education Religious and moral values of their children in accordance with their own convictions"; Article 9 of the European Convention on Human Rights contains a regulation similar to that of Article 18 of the Universal Declaration of Human Rights and Article 18 para. (1) of the International Covenant on Civil and Political Rights. In essence, all these provisions of the Universal Declaration of Human Rights in pacts and international conventions are reiterated by Article 29 para. (1) and para. (6) of the Romanian Constitution.

Thus, the provisions of Article 9 para. (1) of the Education Act can be interpreted only in strict accordance with those of Article 29 of the Constitution, in the sense that "no one can be compelled to adopt an opinion or adhere to A religious belief contrary to his beliefs" and "parents or guardians have the right to ensure, according to their own beliefs, the education of minors under their responsibility". Another interpretation would be obviously unconstitutional.

Article 9 para. (1), the final thesis of the Law on Education, however, allows interpretation according to constitutional provisions: "The pupil, with the consent of the parent or legal guardian instituted, chooses to study religion and confession". The right to "choose" also signifies the possibility of having no religious option. And the "choice", with the "consent of the parent or legal guardian established", ensures the right of the 
child's legal representatives to decide, according to their own beliefs, about the education of minors, as an expression of parental authority.

Introducing religion as a "mandatory discipline" in primary education does not mean religion for students, ignoring the right of the parent or guardian to ensure the education of minors under their own convictions. By combining the second and the final thesis in the structure of Article 9 para. (1) it results that "mandatory" refers to the inclusion of religion as a discipline in the curricula, religion and confession remaining to be chosen or not.

Decision no. 72 of 18 July 1995 on the constitutionality of some provisions of the Law ${ }^{3}$ on Education, published in the Official Gazette of Romania, Part I, no. 167 of 31 July 1995

2. The status of teaching staff in pre-university education can not be acquired through different procedures

The legislative solution declared unconstitutional was enshrined in the provisions of Article 253 para. (1) letters a) and b) of Law no. 1/2011, as amended, provisions that currently have the following content: "Qualified non-tenured teachers who have participated in the last 6 years at the national tenure competition, who has obtained at least 7 grade/average and have a post/department, become tenured in the pre-university education system if the following general conditions are met cumulatively:

a) certifying the viability of the post/department;

b) the Management Board of that school agrees".

The provisions of Article 253 para. (1) letters a) and b) of Law no. 1/2011 establish the general conditions that have to be fulfilled cumulatively by non-qualified teachers to become tenured in the pre-university education system.

Such a regulation in fact establishes a way of acquiring the quality of tenured in pre-university education contrary to the principles that the law establishes for granting the tenure, as well as to the legal system that the law circumscribes the notion of "tenured" in education. Thus, contrary to the provisions of Article 16 para. (1) of the Constitution, discrimination is created regarding the occupation of posts in pre-university education, in the sense that for a certain category of persons - the non-tenured teachers who participated in the last 6 years at the national competition for granting the tenure, which have obtained at least the 7 grade/average and have held a post/department -, this is done only on the basis of the certification of job viability and the agreement of the board of administration of that certain educational establishment.

\footnotetext{
${ }^{3}$ Law on Education no. 84/1995 (Official Gazette of Romania, Part I, no. 167 of 31 July 1995).
} 
The Court held that the status of tenured of pre-university education has a distinct legal regime, this category of teaching staff benefiting from specific rights [for example, for pre-university staff: transfer in the situation of job restriction, assignment to vacant posts/chairs under Article 252 para. (3) of the law, pre-transfer, in accordance with Article 252 para. (5) of the law, the possibility of posting, under the conditions of Article $254^{1}$ of the law, reserving the post or the chair under the conditions of Article 255 of the law, unpaid leave during a school year under the same article, the possibility to occupy positions of director or deputy director under Article 257 of the law etc.].

In view of this specific legal regime, the status of tenured teacher in education is acquired through competition, this being the principle that derives from the systematic interpretation of Law no. 1/2011.

Thus, according to Article 89 of Law no. 1/2011: "In state and private pre-university education, the vacant and reserved teaching positions are occupied through a contest organized at the level of the educational establishment with legal personality, according to a framework methodology developed by the Ministry of Education, Research, Youth and Sport", and, according to Article 254 para. (3) of the same law: "(3) In state and private pre-university education, the teaching positions are occupied through a contest organized at the level of the educational establishment with legal personality, according to a framework methodology developed by the Ministry of Education, Research, Youth and Sport".

Even if the granting of tenured quality under conditions of Article 253 para. (1) letters a) and b) of Law no. 1/2011 is of an exceptional nature, the establishment of this exception must comply with the constitutional norms and principles. The insufficiency of the number of teachers does not justify the distortion of the legal regime of an institution that has a well defined legal structure and the creation of a "parallel" way of granting the tenure in the pre-university education, contrary to the optimal development of the educational process within a predictable and workable national education system.

The criticized norms, in the whole of the regulation to which they belong, set up an institution with a confusing legal regime, which allows the granting of tenure of a teaching staff under conditions other than by the promotion of a competition.

As a consequence, the Court found that the rules of law criticized in this case are discriminatory, since they allow the recognition of the quality of tenured in pre-university education in a way other than the competition, whichis mandatory for all the other persons wishing to accede the teaching positions as tenured. Also, the notion of "viability of the post/chair" used in the criticized law has a clearly imprecise character, while the establishment of the school board's approval condition opens the way for arbitrariness and subjectivism in the field.

Decision no. 106 of 27 February 2014 on the exception of unconstitutionality of the provisions of Article 253 para. (1) letters a) and b) of the National Education Law no. 1/2011, published in the Official Gazette of Romania, Part I, no. 238 of 3 April 2014 


\section{The status of a tenured professor in university education can not be}

\section{acquired through different procedures}

The legislative solution declared unconstitutional was enshrined in the provisions of Article 284 para. (7) and Article 289 para. (7) of the National Education Law no. 1/2011, provisions according to which:

- Article 284 para. (7): "The teaching staff who were granted tenure and who did not exceed the retirement age by 3 years may be recognized by the management board in accordance with the methodology set out in para. (6), under condition that they will renounce of retirement pension for the remaining period as tenured teacher";

- Article 289 para. (7): "The teaching staff who were granted tenure may be recognized annually by the university senate according to the methodology set out in para. (6), under condition that they renounce of retirement pension for the remaining period as tenured teacher".

From the systematic examination of the cited legal provisions it results that the law texts subject to the exception of unconstitutionality practically establish a way of acquiring the quality of titular in education through its "recognition", in a way contrary to the principles that the law establishes for the titularization, As well as the legal regime that the law circumscribes to the notion of "tenured" in education. This creates discrimination regarding employment in education, in the sense that for a certain category of persons this is done without competition, only on the basis of a request and approval by the management board or the university senate, as the case may be.

Even if the "recognition" of the tenured quality under the conditions of Article 284 para. (7) and Article 289 para. (7) of the National Education Law no. 1/2011 is of exceptional character, the establishment of this exception must comply with the norms and constitutional principles. The insufficient number of qualified teachers does not justify the distortion of the legal regime of an institution that has a well defined legal structure and the creation of a "parallel" way of acceeding, even for a short period of time (in the case of pre-university education) to the quality of tenured teacher in education.

As far as higher education is concerned, the introduction of this exception tends to circumvent both the legal framework for retirement and the occupation of teaching positions in higher education. This violates the principle of legal certainty deriving from the provisions of Article 1 para. (5) of the Constitution.

The Court also found that the rules criticized in the whole of the regulation to which they are part of, set up an institution with a confusing legal regime, that of the "recognized tenured". He is a tenured teacher for a fixed period (in the case of pre-university education) and practically for an indefinite period (in the case of university education), after the retirement age and retirement under the law. Such an 
institution designated by the same notion of "tenured", to whom a certain legal regime corresponds according to the Law on National Education no. $1 / 2011$, is capable of violating the requirements of clarity and precision of the regulation imposed by Article 1 para. (3) and (5) of the Constitution. Even though the constitutional texts cited do not explicitly state the requirements on the quality of legislation, by interpreting them in accordance with the Convention for the Protection of Human Rights and Fundamental Freedoms and the case law of the European Court of Human Rights, the Constitutional Court has set a number of criteria to be respected in the activity of lawmaking: "accuracy, foreseeability and predictability so that the subject subject of law can comply with the conduct so as to avoid the consequences of non-observance" (Decision no. 61 of 18 January 2007, published in the Official Gazette of Romania, Part I, no. 116 of February 15, 2007, Decision no. 26 of January 18, 2012, published in the Official Gazette of Romania, Part I, no. 116 of February 15, 2012). Observance of these criteria requires that the notion of "tenured" in education, regulated by the National Education Law no. $1 / 2011$ should have a unique meaning and a unique regime regarding the acceeding to the status that it appoints.

In the light of the foregoing, the Court held that the rules criticized in the present case are discriminatory considering that they allow the management board and the university senate to recognize the status of tenured teaching staff in education in a manner other than the competition which all other persons are compelled to comply in order to to join the teaching positions as tenured teachers. In fact, the legal provisions criticized allow the management board or senates to confer the status of tenured to teachers who have the status of pensioners. Also, by confusing regulation, difficulties arise in terms of interpretation and application.

In view of the above, the Court found that the provisions of Article 284 para. (7) and Article 289 para. (7) of the National Education Law no. 1/2011 are unconstitutional, in violation of the provisions of Article 1 para. (3) and (5) and of Article 16 para. (1) of the Constitution.

Decision no. 397 of 1 October 2013 on the exception of unconstitutionality of the provisions of Article 284 para. (7) and Article 289 para. (7) of the National Education Law no. 1/2011, published in the Official Gazette of Romania, Part I, no. 663 of 29 October 2013

\section{The status of the teaching staff can not be changed by holding other functions or dignities}

The unconstitutional legislative solution was established by Article 129 para. (3) of the Law no. 128/1997 on the Status of teaching Staff, published in the Official Gazette of Romania, Part I, no. 158 of 16 July 1997, provisions according to which: "(3) University professors, members of the Romanian Academy or scientific academies established by 
law, may remain in activity as tenured, which means full-time activity in education up to the age of 70 years. Over this age, they can be kept in activity only with the agreement of the institution they work in, through annual extensions".

Examining the exception, the Court held that the criticized law regulates an extension of the ope legis of working relations with the employer, for university professors members of the Romanian Academy or scientific academies established by law until the age of 70 years. Over this age they will be kept in activity, upon request, only with the agreement of the higher education institution they work in, through annual extensions.

By Decision no. 444 of 26 October 2004, published in the Official Gazette of Romania, Part I, no. 15 of January 5, 2005, the Constitutional Court examined the constitutionality of the provisions of Article 129 para. (1) and (2) of Law no. 128/1997 referred to the provisions of Article 16 para. (1) of the Basic Law regarding the criteria of age for maintaining the activity of university professors and university lecturers with a scientific degree of doctor. Thus, the Court held that age is not among the discriminatory criteria, which violates the equality of citizens, listed in the provisions of Article 4 para. (2) of the Constitution, in this case only the nature of a legal condition for the exercise of a profession, applicable equally to all persons in identical situations, respectively, those who fall within the scope of the legal rule.

In analyzing the grounds of unconstitutionality raised in the present case, the Court found that the criticized legal rules operate a distinction between university professors and university lecturers with a scientific degree of doctor, on the one hand, and university professors, members of the Romanian Academy or academies of sciences organized by scientific fields, established by law, on the other hand, regarding the maintenance in the teaching position, as tenured. Thus, the latter benefit from a prolongation of the employment relationship with the employer until the age of 70 , while university professors and university lecturers with a scientific degree of doctor may be maintained as teaching staff for the same level age, only on request and with the approval of the faculty council and the annual approval of the university senate.

Under these circumstances, the Court found that the text of the criticized law infringes the provisions of Article 16 of the Basic Law, concerning equality of rights of citizens.

In this regard, the Court has consistently upheld what has consistently been established in its case-law in accordance with the case-law of the European Court of Human Rights (Marckx case against Belgium, 1979), namely that "violation of the principle of equality and non-discrimination exists when it applies discriminatory treatment of equal cases without objective and reasonable reasoning, or if there is a disproportion between the aim pursued by unequal treatment and the means used". In the case in question, the establishment of a distinct legal treatment between university professors, irrespective of the title of some of them, has no objective and reasonable 
justification. Both members of the Romanian Academy or academies of science organized by law, as well as university professors and university lecturers with a scientific degree of doctor, are in the same legal situation regarding their teaching activity.

Even from the point of view of keeping in service university professors over the age of 65, according to Article 129 para. (2) of the law, their legal status must be the same, otherwise the constitutional provisions on equal rights of citizens are violated, both categories having the legal status of university professors.

The Court found that, although the establishment of conditions for maintaining the activity is the option of the legislator, such conditions can not be imposed in order to discriminate against persons in the same legal situation without any reasonal and objective justification.

Decision no. 599 of 14 April 2009 on the exception of the unconstitutionality of the provisions of Article 129 para. (3) of the Law no. 128/1997 on the Status of Teaching Staff, published in the Official Gazette of Romania, Part I, no. 329 of 18 May 2009

\section{The state is compelled to ensure the possibility of studying religion,}

\section{while students must have the right of choice}

The legislative solution declared unconstitutional was enshrined in the provisions of Article 9 para. (2), the first sentence of Law no. 84/1995, the law on education, and Article 18 para. (2) first sentence of Law no. 1/2011, provisions having the following content:

- Article 9 para. (2) of the Law no. 84/1995 - "At the written request of the parents or the legal guardian established, the student may not attend the religion classes. In this case, the school situation is finalized without this discipline. Similarly, it is also the case for the student who, for objective reasons, has not been provided with the conditions for attending classes in this discipline";

- Article 18 para. (2) of Law no. 1/2011 - "At the written request of the major pupil, respectively of the parents or of the legal guardian established for the minor student, the student may not attend the religion classes. In this case, the school situation is finalized without the discipline of religion. Similarly, it is also the case for the student who, for objective reasons, has not been provided with the conditions for attending classes in this discipline".

The Court has held that including religion as a school discipline, part of the common trunk, is not an eo ipso problem that could lead to violation of the freedom of conscience, as long as the disputed provisions do not impose obligations to attend courses of a particular religion contrary to beliefs of each. As such, the Court notes that 
the provisions of Article 9 para. (1) of Law no. 84/1995 and Article 18 para. (1) of Law no. $1 / 2011$, are a consecration of the constitutional provisions of Article 32 para. (7) according to which "the State ensures freedom of religious education, according to the specific requirements of each cult. In state schools, religious education is organized and guaranteed by law". Therefore, the compulsory character of Religion as a school discipline is part of the common curriculum, and can not be opposed to the students, since its establishment is aimed at meeting the above-mentioned constitutional requirements, by fulfilling the obligation of the state to include this discipline in the framework plan of education. Consequently, the obligation of studying religion is opposable only to the state which is held by the necessity of organizing religious education by ensuring the teaching of Religion for the 18 recognized cults (see also Article 32 of Law no. 489/2006 on religious freedom and the general regime of denominations, Republished in the Official Gazette of Romania, Part I, no. 201 of 21 March 2014).

The fact that para. (2) of Article 9 of Law no. 84/1995 and 18 of Law no. 1/2011 give the student the right to opt by imposing the possibility of not participating in these courses, consecrates the optional character of the discipline, which, this time, concerns the major student, the parent or the legal guardian established for the minor student.

The Court found that the way in which the legislator regulated by Article 9 para. (2) first sentence of Law no. 84/1995 and Article 18, para. (2), first sentence of Law no. $1 / 2011$, the educational offer referring to Religion discipline, is likely to affect freedom of conscience.

The fundamental law guarantees parents the right to care for and educate their children and includes the right to religious education. Therefore, their right to transmit their own beliefs about religious matters to their children is paramount. Parents also have the right to keep their children away of religious beliefs. However, this right to education does not belong exclusively to parents, the state, which has been entrusted with control over the entire school system, assuming autonomously and concurrent an own education mission, correlated with that of parents. It follows that, on the one hand, there is a negative obligation on the State not to intervene in forming or joining a belief or religious belief, and, on the other hand, there is a positive obligation that, to the extent that the person is manifesting in the sense of studying or accepting the teachings of a particular religious cult or religion, to create the legislative and institutional framework necessary for the exercise of the rights provided by articles 29 and 32 of the Constitution. However, in no case can a person be placed ab initio in the situation of defending or protecting his or her freedom of conscience, because such an approach would contravene the negative obligation of the state, which by virtue of this obligation can not impose the study of religion. Thus, only after expressing the wish of the major student, namely the parents or the legal guardian established for the minor student, to learn through the study the precepts specific to a particular religious cult, the positive obligation of the state to ensure the necessary framework is put in place. In adopting its 
regulations in the field of education, the legislator must take into account the fact that Article 29 para. (6) of the Constitution guarantees the right to religious education and not the obligation to attend religious courses. Under this aspect, the free expression of options necessarily implies the person's own initiative in the sense of attending the discipline of Religion, and not the tacit consent or express refusal. Explaining an opinion from the point of view of the constitutional provisions on freedom of conscience and religion applicable in the field of religious education must always have a positive meaning (the person chooses to study religion) and not a negative meaning (the person chooses not to study religion), because in the second hypothesis the person is presumed to be the one who already has the option of studying, having to act later for his/her exclusion from the study group. Such regulation is nothing more than a coercion of the person in the manifestation of an option, which, in turn, is contrary to the freedom of conscience enshrined in the Constitution.

The Constitutional Court found that the school should be open to religious ideas and values, because, according to the provisions of Article 29 para. (2) of the Constitution, the state guarantees freedom of conscience, which must be manifested in a spirit of tolerance and mutual respect.

Therefore, the state is forbidden to adopt legislative solutions that can be interpreted as being disrespectful of the parents' religious or philosophical beliefs, which is why the organization of the school activity must be subordinated to achieving a conciliatory purpose in the exercise of the functions which Assume them in the process of teaching and teaching religion while respecting the right of parents to provide education in accordance with their own religious beliefs. As part of the constitutional system of values, the freedom of religious conscience is attributed to the imperative of tolerance, especially in relation to the human dignity guaranteed by Article 1 para. (3) of the Basic Law, which dominates the entire value system as the supreme value. This reason excludes, in principle, that activities and behaviors stemming from a certain attitude of belief or non-religious philosophical beliefs are subject to sanctions that the state provides for such conduct, irrespective of the person's motivational beliefs.

In order to fully respect the freedom of conscience and religion, which implies the freedom to belong to or not a religion, as enshrined in Article 29 para. (1), (2) and (6) of the Constitution, the legislator is bound by an obligation of neutrality and impartiality. This obligation is made in the situation where the state watches that these freedoms are respected, giving the possibility to the parents, the legal representatives of the minor students, namely the possibility of the major students to apply for participation in the religion classes.

Decision no. 669 of 12 November 2014 on the exception of the unconstitutionality of the provisions of Article 9 para. (1) and (2) of the Education Law no. 84/1995, Article 18 para. (1) and (2) of the National Education Law no. 1/2011, as well as the provisions of Article 61 para. (3) of the Law no. 47/1992 on the organization and functioning of the Constitutional Court, published in the Official Gazette of Romania, Part I, no. 59 of 23 January 2015 
6. It is unconstitutional the legislative solution that establishes differences between the autonomy of higher education and the autonomy of private higher education

The legislative solution declared unconstitutional was enshrined as the Object of the exception of unconstitutionality, as it emerges from the Court rulling, constitutes the provisions of Article 72 para. (5) of the Law no. 128/1997 on the Statute of the teaching staff, published in the Official Gazette of Romania, Part I, no. 158 of July 16, 1997, provisions according to which: "The attributions and competencies of structures and management positions in higher education are established by the university charter of the institution, according to the law. The decisions of the university senates, the councils of the faculties and the departments, with the exception of the provisions of Article 74 para. (3), shall be taken by a majority of the members present, if their number represents at least 2/3 of the total number of members. Members of these management structures shall have the right to vote deliberately equal".

The Court observed that, according to Article 72 para. (5) of Law no. 128/1997, the attributions and competencies of structures and management positions in higher education are established by the university charter of the institution "according to the law". Thus, the criticized law refers to the concept of university autonomy when it comes to state higher education and academic autonomy, as stipulated by Law no. 480/2006 amending Law no. 84/1995, in the case of private higher education.

In this context, it was recalled that, by expressing the provisions of Article 32 para. (6) of the Basic Law, the Education Law no. 84/1995, republished in the Official Gazette of Romania, Part I, no. 606 of 10 December 1999, regulated in the chapter IX, Section 7, Articles 89-96, the content of the concept of university autonomy, consisting in "the right of the academic community to lead, to exercise its academic freedoms without any ideological, political or religious interference, to assume a set of competences and obligations in accordance with the national options and strategic guidelines for the development of higher education, established by law".

As long as the criticized law only gives expression to academic autonomy, which confers certain rights and freedoms on higher education institutions, the Court notes that the different situations which may result from the application of this principle can not be interpreted as affecting the principle of equality of rights.

At the same time, however, the Court noted that, in the case of private universities, Article 72 para. (5) of Law no. 128/1997 also applies to the concept of "academic autonomy", a concept introduced in the Education Law by Law no. 480/2006, published in the Official Gazette of Romania, Part I, no. 1.025 of December 22, 2006. Starting from 
the premise of private property as an economic foundation of private higher education, academic autonomy grants them different rights and freedoms of those that circumscribe the university autonomy, including the status of professors, such as age limit, promotion in positions etc.

Without denying the economic foundation of private universities, their private property, established by law, without patrimonial purpose and with special affection, the Court found that this foundation can not be the basis of establishing a form of autonomy different from the one established by Article 32 para. (6) of the Constitution, such as how academic autonomy is.

In this regard, the Court noted that the constitutional provisions consecrate and guarantee a single form of autonomy, namely the university, whether it is state higher education or private higher education, autonomy whose content must be identical in both cases.

According to Article $116^{1}$ para. (1) of the Education Law: "Private universities are free, open, autonomous higher education institutions both academically and economically and financially, based on the private property guaranteed by the Constitution", and according to the provisions of Article $116^{2}$ para. (1) of the same law, "The structures and management positions of the private universities, the attributions, the constitution, the duration of the mandates and the age limits of the teaching staff are determined by the university Charter. Final decisions, in this sense, are up to the university".

Under these circumstances, and given the fact that these institutions are part of the national education system, the Court notes that the constitutional principle of academic autonomy must also be reflected in the organization and functioning of the educational process, the status of teaching staff, the promotion in positions of those, the didactic norm etc.

In view of the above, the Court has noted that the provisions of Article 72 para. (5) of Law no. 128/1997 contradict Article 32 para. (6) of the Constitution, insofar as they refer to Article $116^{1}$ para. (1) and Article $116^{2}$ para. (1) of the Education Law no. 84/1995, introduced by Law no. 480/2006, texts which in their turn are unconstitutional because, by way of derogation from the constitutional provisions, they establish a new type of autonomy for private higher education, namely academic autonomy.

Decision no. 731 of 7 May 2009 on the exception of the unconstitutionality of the provisions of Article 72 para. (5) of the Law no. 128/1997 on the Status of Teaching Staff, referred to in Article $116^{1}$ para. (1) and Article $116^{2}$ para. (1) of the Education Law no. 84/1995, published in the Official Gazette of Romania, Part I, no. 395 of 11 June 2009 
Unconstitutional legislative solutions in the field of education

7. It is unconstitutional the legislative solution according to which

sanctions imposed on persons holding eligible management positions in

higher education can not be disputed

The legislative solution declared unconstitutional was enshrined in the provisions of Article 123 para. (5) of the Law no. 128/1997 on the Status of Teaching Staff, published in the Official Gazette of Romania, Part I, no. 158 of 16 July 1997, provisions according to which: "For the eligible management positions in the higher education institutions, the provisions of Article74, para. (2) and (3) apply without any right of appeal".

The Court found that the provisions of Article 123 of Law no. 128/1997 regulate different assumptions regarding the way of setting disciplinary sanctions for teaching staff, auxiliary teaching staff, management, guidance and control staff and the way to communicate these penalties according to the categories of teaching staff to whom they are addressed.

In this context, the provisions of Article 123 para. (5) of the Law no. 128/1997 stipulate that, in the case of persons holding management positions in the higher education institutions, the provisions of Article 74 para. (2) and (3) of the same law, related to the revocation or suspension of position. Thus, the person who has committed the disciplinary offense will be subjected to a revocation procedure by following the same procedure as the one required for his naming in position, or by the vote of the electorate. Also, the Minister of Education may suspend from position the rector of a state or private higher education institution, a suspension that will be subject to validation by the university senate by vote.

Both measures are subject to electors, who have the right to decide to retain or remove from position the person who holds the management position, given that the naming was made symmetrically by the vote of the majority. This is, moreover, a form of manifestation of academic autonomy, which implies, among other things, the possibility of choosing in management positions those persons who can best represent and achieve the objectives of the educational institution, as shown in the provisions of Article 92 para. (3) letter f) of the Education Law no. 84/1995. For these reasons, the revocation decision can not be appealed, which does not mean the violation of free access to justice.

On the other hand, the Court has also found that the provisions of Article 74 para. (2) and (3) of Law no. 128/1997 set a procedural framework in which the measure of revocation or suspension applies, so that the legality of such measures is subject to compliance with these procedural rules. Thus, it is stated that: " $A$ person in $a$ management position can be removed from position by the procedure used for election, at the initiative of one third of the total number of voters. Hearing of the person is 
mandatory". Also, in the case of suspension, it is stipulated that the measure must be duly substantiated, as well as the Senate's obligation to validate or invalidate this decision within 30 days. Invalidation shall be made if the two thirds of the total number of the members of the university senate meet against the suspension measure. In the case of validation, however, the procedure for electing the new rector is triggered. Finally, the law prohibits the commencement of the suspension process during university holidays.

The legal efficiency of these provisions, which is a guarantee for the respect of the rights of the revoked or suspended person, can only be ensured in so far as the lawfulness of the procedure is susceptible to being subject to the control of the courts. Thus, the impossibility of challenging these procedures, provisioned by Article 123 para. (5) of the Law no. 128/1997, represents, from this perspective, a clear violation of the access to justice.

Decision no. 1.614 of 16 December 2010 on the exception of the unconstitutionality of the provisions of Article 123 para. (5) of the Law no. 128/1997 on the Status of Teaching Staff, published in the Official Gazette of Romania, Part I, no. 118 of 16 February 2011 